\title{
Roman Murawski, Filozofia matematyki i logiki w Polsce międzywojennej, Wydawnictwo Naukowe Uniwersytetu Mikołaja Kopernika, Toruń 2011, ss. 243
}

DOI: http://dx.doi.org/10.12775/RF.2017.020

Autor książki jest znany w środowisku polskich filozofów i matematyków z racji opublikowania wielu prac omawiających nurt analityczny w polskiej filozofii oraz z opracowań na temat historii i filozofii matematyki. Prezentowana książka stanowi uwieńczenie jego wieloletnich badań nad historią i filozofią matematyki, których owocem były m.in. wydana w 1995 r. monografia Filozofia matematyki. Zarys dziejów, a także liczne publikacje poświęcone poszczególnym jej przedstawicielom.

Książkę otwiera rozdział poświęcony prekursorom polskiej filozofii matematyki, do których autor zaliczył Jana Śniadeckiego, Józefa Marię Hoene-Wrońskiego, Samuela Dicksteina oraz Edwarda Stamma. Ten ostatni znany jest głównie w środowisku matematyków i niewątpliwie bardzo dobrze się stało, że autor przybliżył jego dorobek także filozofom. Czytelnika niewątpliwie zainteresują w tej części książki zmagania Śniadeckiego z językiem, gdy chciał spolszczyć nazwy łacińskie znane $\mathrm{w}$ geometrii jako sinus, cosinus czy tangens. Dowie się też przy okazji, że już wówczas prekursor polskiej filozofii matematyki przewidywał dominację matematyki w nauce, która „stanie się jeszcze wodzem umysłu ludzkiego we wszystkich poznawaniach" (s. 17).

Roman Murawski znany jest także z kilku interesujących rozpraw na temat matematyki i filozofii Hoene-Wrońskiego. W książce znajdziemy jednak zaledwie kilka stron poświęconych temu oryginalnemu myślicielowi, uznającemu matematykę za środek, za pomocą którego uda mu się odkryć tajemnicę stworzenia. Wroński bowiem uważał, że matematyka jest przykładem narzędzia, którym posługiwał się Bóg, tworząc świat. Postulował więc reformę matematyki, która jego zdaniem powinna zostać wyprowadzona z jednego najwyższego prawa stworzenia, dzięki czemu matematyka posługiwać się będzie wyłącznie pewnikami. Matematyka w tym rozumieniu miała być, obok prawd religijnych, boskim „podarunkiem twórczym” objawionym człowiekowi, dzięki, któremu może on działać na podobieństwo Stwórcy. Dalej czytelnik dowie się, 
że zupełnie odmiennie postrzegał zadanie matematyki inny wybitny myśliciel Samuel Dicstein, wedle którego nie rozstrzyga ona żadnych kwestii metafizycznych, bo służy tylko do badania zjawisk. Pomimo że wspomniany wcześniej Edward Stamm blisko współpracował z Dicsteinem, to również miał odmienne od niego zdanie na temat związków łączących filozofię i matematykę. Stamm dostrzegał, że matematyka także głosi tezy ontologiczne, a stąd jej związek z filozofią był dla niego oczywisty. Znany jest natomiast głównie jako historyk matematyki, a stąd wnikliwie śledził rozwój filozofii matematyki, prowadząc przy tym kompetentne polemiki z Bertrandem Russellem oraz Natorpem.

Można przypuszczać, że przytoczenie w książce poglądów właśnie tych postaci jest celowym zabiegiem autora, który na ich przykładzie wskazał rozmaitość stanowisk, jakie zajmowano w obrębie filozofii matematyki. Problem polega zatem nie tylko na rozgraniczeniu obszarów zainteresowania tych nauk, ale także na określeniu przedmiotu samej matematyki. Wydaje się, że autorowi ostatecznie udało się dzięki temu wykazać słuszność tezy Stamma, że matematyka nie jest nauką statyczna, bo jej przedmiot zainteresowania ewoluuje, i dlatego dawno już przestała być nauką tylko o wielkościach, gdyż zaczęła wkraczać w obszary zainteresowania, w których zmysłowe doświadczenie przestaje wystarczać.

Drugi rozdział swej książki Roman Murawski poświęcił polskiej szkole matematycznej. Podobnie jak w przypadku filozofii skupiała się ona w dwóch ośrodkach: Warszawie i Lwowie. Dla czytelników niezorientowanych $\mathrm{w}$ historii filozofii matematyki bez lektury tego rozdziału mogłoby się wydawać, że jest ona domeną wyłącznie filozofów. Bardzo dobrze się zatem stało, że autor wykazał również powinowactwa tych dyscyplin związane zapewne ze zbliżonym poziomem abstrakcji, na jakim muszą poruszać się ich przedstawiciele. Można by to ująć w stwierdzeniu, że z filozofii do matematyki jest równie blisko, jak z matematyki do filozofii. Nic zatem dziwnego, że tak wielu wybitnych matematyków parało się filozofią i na odwrót.

Wedle autora omawianej książki najważniejszymi postaciami warszawskiej szkoły matematyki byli Władysław Sierpiński, Zygmunt Januszewski oraz Stefan Mazurkiewicz. Przy okazji omawiania poglądów Sierpińskiego wskazane zostały także dwa zasadnicze problemy filozofii matematyki: problem związków pomiędzy „matematyką czystą" a matematyką stosowaną oraz problem "matematyczności świata fizycznego" (s. 34). Czytelnik z tej części książki dowie się, że termin „logistyka” był wówczas synonimem logiki matematycznej (logiki symbolicznej), co staje się zrozumiałe w świetle określonej przez Janiszewskiego zbieżności pola problemowego logiki i matematyki. Wedle definicji sformułowanej przez tego autora logistyka to "logika formalna (tj. nauka o formach czystej myśli) posługująca się metodą matematyczną" (s. 38). 
Zarazem podkreślił też, że logika matematyczna jest nowym działem matematyki, a nie jakąś nową jej metodą czy też narzędziem. Przy tej okazji Roman Murawski wprowadza nas w atmosferę życia środowiska polskich matematyków, którzy przed odzyskaniem niepodległości mieli określone trudności $\mathrm{w}$ uczestniczeniu $\mathrm{w}$ wymianie międzynarodowej. W efekcie tego teoria mnogości w Polsce międzywojennej dopiero zyskiwała prawo obywatelstwa. Implikowało to $\mathrm{w}$ znacznym stopniu treści prowadzonych wówczas dyskusji naukowych. W podsumowaniu charakterystyki szkoły warszawskiej autor stwierdza: „w szkole tej nie hołdowano żadnej konkretnej doktrynie filozoficznej w zakresie filozofii matematyki" (s. 47-48). Niemniej jednak wyraźnie odróżnia ją od szkoły lwowskiej, w której logika nie zawsze była traktowana jako samodzielna dyscyplina, choć niekiedy także tylko jako narzędzie. Dla przykładu sam Hugo Steinhaus uważał ją jedynie za narzędzie dedukcji. Zorientowanego w historii filozofii czytelnika może też nieco zmylić zaliczenie Leona Chwistka do lwowskiej szkoły matematycznej, gdyż $\mathrm{z}$ reguły jest on postrzegany jako filozof i to niekoniecznie związany ze Lwowem. Takie usytuowanie Chwistka staje się jednak zrozumiałe, jeśli zostanie uwzględniony fakt, że od 1930 r. był on profesorem logiki matematycznej właśnie na Uniwersytecie Jana Kazimierza.

Zasadniczą częścią książki jest rozdział poświęcony zagadnieniom filozofii matematyki poruszanym w lwowsko-warszawskiej szkole filozoficznej. W ramach tej części autor analizuje także poglądy Andrzeja Mostowskiego oraz Henryka Mehlberga, których zgodnie z już utrwaloną tradycją zalicza się do drugiego pokolenia uczniów tej szkoły. Prezentację poglądów tej szkoły rozpoczyna Jan Łukasiewicz, który choć nie był matematykiem, to wywarł ogromny wpływ na całą matematykę. Autor trafnie zalicza go do najwybitniejszych filozofów matematyki, o czym świadczą zwłaszcza jego prace na temat logik wielowartościowych. Czytelnika zapewne zainteresuje $w$ tym rozdziale omówienie sporu Stanisława Zaremby z przedstawicielami szkoły lwowsko-warszawskiej na temat istnienia zdań pozbawionych treści. Przy okazji był to spór o relację logiki do matematyki, bo według Zaremby logika miała co najwyżej znaczenie pomocnicze dla matematyki. Nasuwa się tu jednak uwaga, że skoro autor przedstawił stanowisko Łukasiewicza dotyczące odwieczności prawdy, to mógł także wspomnieć o polemicznym stanowisku w tej kwestii głoszonym choćby przez innego reprezentanta szkoły Twardowskiego, Stanisława Leśniewskiego. Autor przedstawia także Łukasiewicza jako swego rodzaju buntownika, gdyż to właśnie on zapoczątkował zwrot antypsychologiczny w całej szkole, który zapewne $\mathrm{w}$ jakiejś mierze doprowadził do rozejścia się naukowych dróg założyciela szkoły z niektórymi jego uczniami.

Czytelnika zorientowanego w problematyce badań szkoły lwowsko-warszawskiej może zaskakiwać omówienie w następnej kolejności po- 
glądów Zygmunta Zawirskiego. Niemniej jednak jest to konsekwencją pewnej wspólnoty przemyśleń obu filozofów, którzy rozwój logistyki wywodzili ze szkoły stoików, a w swych rozważaniach chętnie odwoływali się do poglądów Whiteheada i Russella zawartych w „Principia mathematica". Właśnie to powinowactwo spowodowało zapewne, że w książce filozofia matematyki Stanisława Leśniewskiego została zaprezentowana dopiero w trzeciej kolejności. Także przedstawienie w dalszej kolejności poglądów Kotarbińskiego wynika z relacji, jaka zawiązała się z poglądami Leśniewskiego $\mathrm{w}$ toczonej pomiędzy nimi polemice $\mathrm{w}$ kwestii odwieczności prawdy. Ten właśnie problem, który pojawił się już u zarania idei logiki wielowartościowej łączył w pewien sposób większość reprezentantów szkoły lwowsko-warszawskiej zaprezentowanych w książce Romana Murawskiego, którzy bynajmniej nie reprezentowali jednolitego w tej kwestii stanowiska, stając choćby jak Leśniewski i Kotarbiński na odmiennych pozycjach $\mathrm{w}$ toczonych polemikach. Jednakże to Kazimierz Ajdukiewicz dostrzegł jako jeden z pierwszych doniosłość propozycji Łukasiewicza, a także możliwość wsparcia w sporze z Leśniewskim stanowiska Kotarbińskiego. Przypomnieć tu warto, że Ajdukiewicz stwierdził w „Zagadnieniach i kierunkach filozofii”, że „Logika formalna jest obok psychologii empirycznej jedyną dyscypliną filozoficzną o charakterze wybitnie naukowym". Jego zainteresowania filozofią matematyki były więc naturalną konsekwencją takiego poglądu.

Alfred Tarski, którego pozalogiczne dokonania są mało znane, w książce Murawskiego został przedstawiony nieomal jako pełnokrwisty filozof. Autor podkreślił przy tym sympatie Tarskiego do Kotarbińskiego i zarazem do nominalizmu, co owocowało pełną szacunku postawą wobec twórcy reizmu, a w zasadzie tylko deklaratywną aprobatą dla jego koncepcji. Tę ambiwalencję autor interesująco tłumaczy: „Otóż wynikało to z ducha i kanonu ideowego polskiej szkoły matematycznej. Według nich badania naukowe nie powinny być krępowane żadnymi apriorycznymi założeniami filozoficznymi. Powinno się stosować dowolne - byle poprawne - metody badawcze, a przekonania i poglądy filozoficzne są prywatną sprawą badacza i nie powinny mieć żadnego wpływu na jego badania matematyczne. Zgodnie z tym Tarski mógł «prywatnie» czuć się nominalista, a jednocześnie bez skrępowania i niepokojów o niezgodność z tą doktryną stosować w swoich badaniach metamatematycznych infinitystyczne" (s. 154-155). Według Murawskiego podobne stanowisko zajmował także inny wybitny logik Andrzej Mostowski, co wydaje się zrozumiałe, jeśli zostanie uwzględniony fakt, że był on uczniem samego Tarskiego. Autor i przy tej postaci podkreśla fakt unikania wszelkich komentarzy filozoficznych, co być może, jak w pewnym momencie sugeruje treść książki, wynikało z przyczyn ideologicznych, gdyż w powojennych realiach filozofia została usunięta z nauczania na poziomie akademickim, a logika jednak pozostała, choć miała być 
nauczana w oderwaniu od wszelkich związków z filozofią. Tym samym praktyka dydaktyczna być może w jakiś sposób zdeterminowała zawężenie obszaru dociekań naukowych Mostowskiego.

Prezentację filozofii matematyki w szkole lwowsko-warszawskiej kończy krótki, ale wielce interesujący podrozdział poświęcony Henrykowi Mehlbergowi, po czym autor wyodrębnia ośrodek krakowski, w ramach którego autor umieścił Jana Śleszyńskiego, Stanisława Zarębę oraz Witolda Wilkosza. Niemniej w świetle lektury nie ulega wątpliwości, że polska filozofia matematyki w okresie międzywojennym została zdominowana przez przedstawicieli szkoły lwowsko-warszawskiej, bo nawet jeśli autor przywołuje postacie spoza tej szkoły, to praktycznie zawsze $\mathrm{w}$ związku z ich komentarzami na temat prac jej przedstawicieli lub w łączności z problemami, które właśnie oni wprowadzili do polskiej nauki.

Niemniej jednak lektura całej książki jest sporym wyzwaniem dla każdego czytelnika. Autor bowiem z dużą swobodą porusza się po meandrach współczesnej myśli matematycznej, a stąd lektura wymaga co najmniej ogólnej orientacji w historii matematyki i logiki. Niekiedy jednak nawet taka wiedza nie wystarcza, bo dla przykładu odwołania do Cantora, Carnapa, Gödla czy Hilberta wymagają także pewnej znajomości logiki formalnej (matematycznej). Czytelnika zorientowanego w problematyce nie powinno zatem dziwić zakończenie na postaci Mehlberga prezentacji szkoły lwowsko-warszawskiej, bo przecież to właśnie on pokusił się o opracowanie historii logistyki, a także podjął próbę opracowania nowego jej wariantu, który nazwał logistką pluralistyczną. Wydaje się, że jest to trafne rozwiązanie, bo w ten sposób przegląd koncepcji filozofii matematyki wypracowanych w szkole lwowsko-warszawskiej staje się $\mathrm{w}$ pewnym sensie domknięty. Zarazem jednak uważny czytelnik zauważy spójność ideową rozważań z zakresu logicystki i matematyki, które w tej szkole prowadzono. Nawet polemiki prowadzone pomiędzy poszczególnymi przedstawicielami tej szkoły tego wrażenia nie zmienią. Autor po prostu stara się czytelnikom uświadomić, że polska filozofia matematyki podejmowała specyficzny obszar dociekań naukowych, który można potraktować jako odrębną całość. Istnieje bowiem co najmniej kilka obszarów badawczych, które w jakiś sposób ukierunkowały tę szkołę, zwłaszcza w jej lwowsko-warszawskim wydaniu. Po pierwsze, w każdym nieomal przypadku przewija się problem reizmu Kotarbińskiego, do którego przedstawiciele tej szkoły zawsze w jakiś sposób się ustosunkowywali. Wiązał się z tym nawet swego rodzaju polski spór o uniwersalia. Paradoksalnie nie wykluczało to np. swoistości i odrębności pojmowania poszczególnych pojęć, jak choćby pojęcia „przedmiot”. Przedmioty bowiem muszą jakoś istnieć, ale zarazem być może ich istnienie nie wymaga uprzedniej percepcji, choćby dlatego, że jak chciał Zawirski „zasada logiczna nie może wprowadzić istnienia inaczej jak 
tylko w formie hipotetycznej" (s. 92). Kluczowe jednak znaczenie ma w tym przypadku stanowisko wobec relacji łączących logikę z matematyką. Można zauważyć w tym przypadku pewną ewolucję stanowisk, które początkowo koncentrowały się na tym, aby zaakceptować status logiki formalnej jako dyscypliny matematycznej, aby ostatecznie w wydaniu Mehlberga zakładać, że matematyka jest po porostu zaledwie częścią logiki. Rozważania na ten temat zaowocowały powstaniem polskiej szkoły metodologii nauk dedukcyjnych, a wrażenie to utwierdza się, gdy czytamy, że to właśnie Ajdukiewiczowi zawdzięczamy także nie tylko klasyfikację nauk, ale zwłaszcza wyodrębnienie stadiów rozwoju nauk dedukcyjnych: „aksjomatyczne, intuicyjne, aksjomatyczne intuicyjne, a wreszcie aksjomatyczne abstrakcyjne" (s. 130).

Przyjęty układ książki potwierdza zapowiedź zamieszczoną na okładce, że jest ona $\mathrm{w}$ pewnym sensie dopełnieniem znanej publikacji Jana Woleńskiego Filozoficzna szkoła lwowsko-warszawska. Przedstawicielom tej szkoły poświęcono bowiem zdecydowaną większość jej treści. Niemniej jednak $\mathrm{w}$ okresie przedwojennym uprawiano filozofię matematyki nie tylko w jej ramach. Zauważalna jest więc nieobecność na stronach książki przedstawicieli tzw. Koła krakowskiego, skupionych wokół Innocentego Marii Bocheńskiego oraz Jana Salamuchy. Brak także wzmianki o pracach twórcy wielce oryginalnej koncepcji „,architektoniki świata" Benedykta Bernsteina. Choć dziś wiadomo, że realizacja zamysłu Bernsteinowi ostatecznie się nie powiodła, to jednak sam pomysł zasługuje jak najbardziej na wzmiankę i krótkie omówienie. Wszystko to nie umniejsza jednak w niczym faktu, że dzięki pracy Romana Murawskiego doczekaliśmy się bardzo cennej poznawczo i oczekiwanej przez środowisko polskich historyków nauki syntezy osiągnięć w zakresie filozofii matematyki.

Stefan Konstańczak

Uniwersytet Zielonogórski s.konstanczak@ifil.uz.zgora.pl 